\title{
Why beauty and why now? Historical perspectives of the contemporary discourse on beauty ${ }^{*}$
}

\author{
Adrián Kvokačka \\ University of Presov, \\ Ul. 17 novembra 15, 080 01, Prešov, Slovakia
}

For citation: Kvokackka A. Why beauty and why now? Historical perspectives of the contemporary discourse on beauty. Vestnik of Saint Petersburg University. Philosophy and Conflict Studies, 2018, vol. 34, issue 4, pp. 515-522. https://doi.org/10.21638/spbu17.2018.405

\begin{abstract}
The term "beauty" has been a key category of aesthetic thinking for a long time. Relevancy of beauty of art, represented in ancient times by Plato's transcendental theory of beauty or more factual inductive beauty of empirically oriented Aristotle and many others thinkers, placed beauty as a priority category of the world, including the world of art. Modern approaches primarily follow Kantian and Hegelian idealistic aesthetics of beauty, however, the state of today's art world, or in the broader context, the aesthetic world of the $20^{\text {th }}$ century, doubt beauty and even dethrone it from its pedestal. Does it make sense today to examine about beauty of art? Has beauty as an attribute of art not ended its journey together with the idea of the end of art? The paper aims to follow the connotations of beauty losing its place in art in the context of the end of art (Hegel and Danto) or end of its history (Belting). Contemporary new thematization of beauty after a century dominated by the ugly or the sublime in art (from Kant's and Lyotard's point of view) is an important shift showing beauty not only as a remnant of history but rather as a vital source that is worthily gaining renewed attention and new varieties with the spread of interdisciplinary approaches.
\end{abstract}

Keywords: aesthetics, end of art, beauty.

The renewed interest in beauty nowadays is a testimony of an important transformation that shows beauty not just as a remnant of history, but rather as a vital source that is acquiring its rightly regained attention as well as new varieties thanks to interdisciplinary approaches. The level of stability of this interest, its potency in exposing the society anew to the aesthetic world, can be considered only when the reasons for the loss of the status of beauty and its return (as a partial renewal of its past state) are understood. Such a non-trivial exploration of beauty is signalized by A. Danto when he explains that "the withdrawal from the artistic consciousness of the idea of beauty is a kind of crisis. Even if beauty has become less important for visual art, as opposed to the philosophical tradition, it does not mean that it would be unimportant in the lives of man. (...) In any case, I have arrived at the conclusion that when, as a philosopher, I write about beauty, I turn to the deepest problem that exists" [1, p.44]. I believe that the decade which has elapsed since

* This paper was supported by VEGA Grant Agency under the contract No. 1/0531/17 150 Years of "The End of Art" in Reflections and Analysis of Philosophical, Aesthetic and Art Theories.

(c) Санкт-Петербургский государственный университет, 2018 
these words were uttered has imbued this search with meaningful impulses which we will try to expand in this paper.

Beauty in the History of Aesthetic Thought. Beauty was considered to be the central category of aesthetic thought. It permeated the entirety of a person's being and his preconceptions about the world; beauty was the natural language of human beings that configured the cosmos in a mathematical, teleological and religious manners. Influential thematizations of beauty in ancient times and the Middle Ages equipped aesthetic thought with defined frameworks of beauty as an idea, unity, integrity, luminosity, proportion, harmony etc., and at the same time, these frameworks opened the scope for its reflection. One of the most productive approaches of ancient thought was the Platonic understanding of beauty as a transcendent idea. This is the idea of the trans-sensational world, purely spiritual, residing in the true world, illuminating the sensational world by its reflections, echoes, by the imprints of beauty. It became the central category for Plato, who by establishing the relationship between beauty (as the good) and truth, put the claim of art (mainly, poetry) to truth in confrontation with the claim of philosophy to the same thing. In spite of that, artistic beauty unwaveringly continues to maintain and even gains a paramount position, perhaps, paradoxically, also thanks to the Platonic aesthetic tradition that had been inspirational for a significant amount of time during the Middle Ages, and even Modern times. Such duality of the artistic claim to the embodiment of beauty, and the philosophical claim to its integration into the framework of knowledge brought about many forms of the idea of beauty throughout history: the beauty of the body, the beauty of reasoning, the beauty of life, beauty as an idea, the beauty of nature, the beauty of art, the beauty of the cosmos, the beauty of god, the beauty of the world, etc. Thus, the assertion that beauty has become the center of aesthetic thought and aesthetic expression (including artistic expression) is legitimate and reasonable. The exploration of the issue of beauty in Modern times is similar. The rise and rebirth of art in the Renaissance - by its partial rejecting the subservient role in the relationships with religion, coupled with spreading humanism and the new orientation of philosophy in response to the change in man's place in the world - enriches the beauty of art. New connotations emerge that reproduce not only the artistic ancient ideal, but also the philosophical revision of the category of beauty through the motifs of idealization, thus offering its independence from the mimesis of the world of nature. The rightful elevation of beauty to the center of the aesthetic world, including art itself, was concluded in the age of Enlightenment, which "has given beauty the primacy it had been enjoying until recently" [1, p. 92]. Not even the heavily criticized Kant's disinterest in the aesthetic condition, or other modalities of the judgement of taste in beauty can change it. Personally, I think that the subjectivation of beauty that Kant postulated can be seen as the borderline position of our definition of beauty; on the other hand, introducing beauty as universally accessible transcendental subject in the form of a harmonic free play of cognitive abilities without any claim to the knowledge of the thing in itself, constitutes an ambitious project announcing the state of the subject conducive for reflective judgement. Such a search for the sensus communis of aesthetics with its claim to universal validity, will position the category of beauty into the epicenter of aesthetics in its entirety as the beauty of nature (pulchritudo vaga) as well as the beauty of art (pulchritudo adherens). Integrating the sublime into the framework of aesthetics in a distinctive manner (even though this integration is disparaged as being inevitable for a century that is so openly and strongly preoccupied with these two categories), along with a coherent analysis of art, genius, taste, 
etc. these days, can seem a key step towards aesthetics of the last hundred years. Scruton comments on this unending debate about the topicality of Kantian aesthetics nowadays, "I don't say that Kant's theory is right. But it provides an interesting starting point to a subject that remains as controversial today as it was when Kant wrote his third Critique. And one thing is surely right in Kant's argument, which is that the experience of beauty, like the judgement in which it issues, is the prerogative of rational beings. Only creatures like us - with language, self-consciousness, practical reason, and moral judgement - can look on the world in this alert and disinterested way, so as to seize on the presented object and take pleasure in it" [2, p.33]. The second influential branch of the modern reflection on beauty can be traced back to Hegel who proclaims the "reconstruction" of aesthetics as a philosophy of beautiful art. As far as the focus of our topic is concerned, he is an ambivalent actor. On the one hand, he shows the beauty of art as being born out of the spirit, thus surpassing the beauty of nature as art is the creation that represents beauty as an idea, and simultaneously embodies the content of the possibility of presenting reason in a sensual manner. He is thus connected to the triad: art - religion - philosophy. On the other hand, he advocates the proposition of the end of art, because "art, considered in its highest vocation, is and remains for us a thing of the past. Thereby it has lost for us genuine truth and life, and has rather been transferred into our ideas instead of maintaining its earlier necessity in reality and occupying its higher place" [3, p. 11]. Hegel himself does not use the term "death of art", which was frequently attributed to him, he does not even mention the end of art anywhere. He openly acknowledges that art is becoming outdated because it has been surpassed by philosophy. Modern art has ceased to be as important as it used to be in the Middle Ages or ancient times. "The beautiful days of Greek art and the golden age of the Middle Ages are gone" [3, p. 10]. In past cultures, art played a cardinal role because it was the chief medium of representing the religious, ethic, and overall world view. Because modern age is much more rational, the traditional function of art is nowadays better maintained by philosophy. Hegel's approach is still compatible with the future of art. To say that art does not play a cardinal role in modern culture does not mean that it should end, or is ending, but in order for art to continue to exist, it should assume the form of subservient art. "Art can be used as a fleeting play, affording recreation and entertainment, decorating our surroundings, giving pleasantness to the externals of our life, and making other objects stand out by artistic adornment" [3, p. 62]. Whether it is surprising or not, Hegel anticipated what today we understand under the term "mass art", which does not cooperate with beauty premeditatedly. In a more general frame, beauty has always been a part of the intimate dimension of humans; its ideal is always a part of our consciousness. Beauty has always had the connotations of anthropological constants; for a human being, its presence is the saturation of his needs, and its absence is experienced as a loss. Interaction with the aspects of beauty had a psychagogic effect on our soul, it offered éthos, it was part of education, it harmonized people, it was seen as an ideal - the ideal of the completion of the structure, and the defining element of the right measure, the symbol of the moral good. In spite of that, people chose to forsake it. Why are we risking a state in which "the destruction of beauty would lead us to an insufferable world where it would be impossible to experience a full human life?" [1, p.93]. Of course, there are several reasons for that.

The Disappearance of Beauty. Beauty has lost its position because, along with other classical aesthetic categories, it was exposed to new conditions that fundamentally changed 
its agency. In the context of modern and postmodern art, aesthetic categories seemed to be non-functional terms; therefore, they ceased to be able to refer to different modes of the world of aesthetics and to arrange it somehow. If the purpose of aesthetic theory is to be the answer to the changes of the world of aesthetics, to be the guide in this more and more fluid domain, then the thing with which aesthetic theory explains this domain is its categorial apparatus. The consistency of the terminological apparatus, the ability to explain the relations between its individual parts, belongs to the tasks of aesthetics as a discipline of philosophy, and simultaneously demonstrates the relevance of the fixed aesthetic terminology for contemporary art, and for various fields outside art as well. The critical reservations towards beauty in the $20^{\text {th }}$ century are a reaction to the tendency to explain beauty as an enclosed term (through the prism of its previous meanings) which has always documented certain forms of beauty as existing in the context of historical, compositional, genre, or stylistic conditions under which a work of art or an aesthetic state has been created through its perception. That is why an internally conditioned harmony (historically non-transferable) between ancient knowledge and the depiction of beauty, between the medieval knowledge and the depiction of beauty, etc. exists; a harmony that represents the realization of creation and the appraisal of the beauty of art through a set of sufficient conditions that justify using this category, which can be determined on the basis of knowledge and the analysis of works of art. To use a concrete category means to compare the current aesthetic state of the subject with the whole of past experiences that were internally organized by the functioning of the term "beauty". Each and every new example, when it comes to the conditions of the validity of beauty, reorganizes the previous consensus with ensured repetition before the rules for this kind of appraisal are established. In the moment of such destabilization as the Avant-garde and modern art offer, aesthetic theory must agree with the extending of the term "beauty" beyond its original boundaries, or designate the term as invalid and search for a new categorial apparatus. The result of preferring the restricted use of classical aesthetic categories, even that of beauty itself, is that the Avant-garde and modern art do not use beauty and criticize it, and instead purposefully favor the ugly, and later the sublime. The upheaval that the displacement of beauty from the center has caused represents the destabilization of the whole of aesthetic categories. The historically present asymmetry between aesthetic categories and the attempt to find a central aesthetic term, which has culminated in the long-standing prioritization of beauty, has caused uncertainty and a seeming loss of the aesthetic world as such. This situation becomes all the more complicated when the ties of other aesthetic categories to the term beauty are accentuated. The asymmetry grows because practically all other aesthetic categories have been derived from beauty [4]. This destabilization has undoubtedly impacted the consumers of art and the fluctuation of the aesthetic world - uncertainty has become the emblem of the era. The end of artistic beauty is closely tied to Hegel's anticipated end of beautiful art. Hegel's successor, Danto, reminds us that a close connection between art and beauty has always existed. He also adds: "I have grasped the energy of the artistic Avant-garde in order to uncover the rupture between art and beauty (because art based on other terms does exist. $-A$. K.) which before was unimaginable and which has remained unimaginable long after it was exposed, mainly because the connection between art and beauty was grasped because of the strength of the a priori inevitability" [1, p.60]. Beauty was dethroned as in the background of the discontinuous situation in the history of art of the $20^{\text {th }}$ century, at the time when mimetism loses principal references on account of 
simulacra, the primacy of beauty discredited by the Avant-garde that exhibits great instability is substituted by the sublime with a certain tendency towards stability. "The beautiful is perhaps not quite as autonomous as it appears and as Kant would like" [5, p. 33], which is why Nancy directly claims that beauty is unstable and is perpetually threatened by "the slide into the agreeable" [5, p.33] in which it loses its quality of beauty. In the Kantian sense, it could be added that beauty will not be judged by the pure judgement of taste, but by empirical judgement. "In the beautiful as satisfied or satisfying, the beautiful is finished and art along with it" [5, p.33], however, this instability can simultaneously bring beauty to the sublime, and Nancy believes that beauty may attain its pure quality only by stepping out of itself through the sublime: "Indeed, the beautiful is perhaps only an intermediate, ungraspable formation, impossible to fix except as a limit, a border, a place of equivocation (but perhaps also of exchange) between the agreeable and the sublime" [5, p.33], and in itself, it does not maintain any position. Beauty can become beauty only when it is above itself, when it is suspended and unfinished in the sublime, or it ends in philosophy - thus Nancy repeats Hegel's proposition.

The shift away from beauty is also attributed to the fact that "beauty in some way trivializes that to which it belongs" [1, p.57]. The beautiful becomes superficial, common, cheap, and ordinary at the moment when beauty is seized by marketing, cultural industry; when sensual beauty is kitschy, and bodily beauty inappropriate, it is then when beauty as a value ends, and beauty and its derivatives emerge as a product. The change in the society, saturated and anesthetized, was the stigma of the consequences of beautifying the world. The aesthetic has flooded the world of people by a uniform resemblance to beauty, by a comfortable undisruptive resonance of the aspects of the world with a very general and ephemeral memory of beauty of the art of the past, or a direct reference to a socially and conventionally affirmed beauty of the body or fashion that were "allowed" to remain the domain of "positive deviation", silently tolerated or boisterously worshiped.

Beauty regained. The renewed interest in beauty is an attempt at saving what is an existential part of a human being. Beauty renews itself by repeating a historical pattern, when aesthetics formulates its basis in its relation to nature. "Nature, unlike art, has no history, and its beauties are available to every culture and at every time" [2, p.59]. In the $20^{\text {th }}$ century a strengthening tendency of aesthetics emerges which purposefully devotes a significant part of its attention to the area that is beyond the boundaries of art, or, rather, what is nowadays presented as art. The considerable fluctuation in an attempt to define it, which was determined by the state of art in the first half of the $20^{\text {th }}$ century, and deepened by Danto in his memorable study called "Artworld" [6], as well as processes initiated by all this in 1966, paved the way to a different, and, at least for the Anglophone world, innovative approach - Hepburn's work "Contemporary Aesthetics and the Neglect of Natural Beauty" [7] , in which he commenced a new exploration of the aesthetics of nature. This fully legitimate direction was taken up by aesthetics, and alongside the emerging theoretical basis of the institutional theory of art, post-structuralism, postmodernism, and analytical aesthetics, tracing the peripeteias of art and its concept, aesthetics uncovers traditionally marginalized themes, themes that were sidelined, themes such as everyday aesthetics, nature, the environment, gender, and others [8, p. 375]. All of this emerges with a wave of interest in the second half of the $20^{\text {th }}$ century, and extends its scope very openly by including other fields in order for the problem of the environment to become pivotal. Interest in such themes renews the topic of beauty outside art, and, as 
Scruton notes, it contributes to something universal: "But there was another, and more philosophical cause, of this interest in natural beauty. If it was to have its place among the objects of philosophical enquiry then beauty, or the pursuit of it, should be a human universal" [2, p.58]. A new approach emerged in the 1990s. In 1993, Dave Hickey “... provocatively declared that the defining problem of the decade is beauty; his proclamation viewed as an exciting notion" [1, p. 37]. In retrospect, Danto says that this proclamation was premature $[1, \mathrm{p} .166]$, but perhaps it was just this that initiated a large number of theoretical publications and events which embraced the topic of beauty, thus taking it seriously. Paradoxically, this rescue operation has somehow omitted art that has not changed its character, intention or expression, and currently prolongs post-historical art that culminated in the project of postmodernism, in its experimentation and eclecticism that is strikingly similar to Danto's characteristics of artistic creation after the end of art, when he says that it can only "combine and recombine the known forms" [9, p. 2]. 20 $0^{\text {th }}$ century art changes itself from representing to presenting, and from symbolic art to selfquestioning art. Self-reflection of meaning has changed art which begins to ask questions not only pertaining to its meaning, but employing philosophy, thus giving answers to "expressed" questions that are outside its boundaries. "The historical stage of art ends the moment we realize what is art and what is its purpose. Artists have opened the way alongside philosophy, and the moment, when this task has to be given to philosophers, has come" [9, p. 16]. And philosophy of the end of the $20^{\text {th }}$ century, finding itself in a crisis of rationality and sciences, took charge of it in a truly responsible manner, even though without any tangible results in the sense of defining the concept of art, only to forever negate this effort by discrediting its purpose. The ways for aesthetics outside art are being opened for the issue of minimal beauty in the aesthetics of everyday life that demands new thematization of the aesthetic experience that is unable to prolong experience with art outside the domain of art. Similarly, even the concept of aesthetic experience undergoes an attempt at its rescue, for instance, in Shusterman's concept of somaesthetics, a discipline that is inherently interdisciplinary, by moving aesthetics beyond the boundaries of art whose goal can be seen in its basic "provisional" definition. "Somaesthetics is aimed at the critical study of the body as a place of sensory aesthetic assessment and creative self-transformation and its improvement" [10, p.302]. Somaesthetically governed accentuation of the partial aesthetic character in which ordinary, everyday things may be appraised aesthetically through their perception, thus transfigures into a specific experience, exposes everyday objects at the moment of their transformation. It is here that the aesthetic appraisal of everyday life assumes a position similar to the one that is realized in its contact with art (including feelings, experiences, emotions), but without us feeling the problematic, interpretational difficulty of high art. The question that becomes central is the "overlooked existence of beauty" and its attainability for human beings.

Complementary to these processes, an anti-Kantian intention in transatlantic aesthetics that tries to find the opposite of disinterestedness in aesthetic perception and advocates the concept of involvement is beginning to gain strength. In 1991, Berleant said: "There is an alternative to the Enlightenment's aesthetics of distance and disinterestedness, which is a history more than a tradition in Western culture. $\langle\ldots\rangle$ Engagement is the signal feature of the world of action, of social exchange, of personal and emotional encounters, of play, of cultural movements like romanticism and, as is our claim here, of the direct and powerful experiences that enclose us in situations involving art, nature, or 
the human world in intimate and compelling ways" [11, p. 44]. In an unpublished paper at the IAA congress in Seoul titled "Subversive Beauty" he recalls his propositions: "Aesthetics has traditionally been concerned with understanding the experience of beauty in the arts and in nature. In the contemporary world, however, aesthetic values are no longer confined to the museum and the scenic drive where they are honored but kept isolated and innocuous. Aesthetic experiences and values have now become increasingly prominent in all areas of modern life, raising conflicts with values in morality, religion, economics, environment, and social life". Such a manner of revealing the aesthetic dimension of the world opens one of the ways, including that which, in Scruton's words, may be called minimal beauty, "which is permanent interest of rational beings, as they strive to achieve order in their surroundings and to be at home in their common world" [2, p. 96]. Revealing beauty through an engaged aesthetics, the everyday aesthetics is on today's to-do list. It is true that various alliances between sciences, for example, neuroaesthetics, can reveal the way when and with what intensity a thing appears to be beautiful by disclosing the activity of neural centers in test subjects, etc.; however, they cannot answer the question why the renaissance of beauty as a value belongs to the existential questions inherent to human beings. There is nothing else to do but to undertake this task, whether by means of aesthetics and philosophy, or by means of the art that engages in philosophizing. We are already trying the first possibility, but we still do not know how real the second one is.

\section{References}

1. Danto, A.C. (2008), Zneužitie krásy [Abuse of beauty], Kalligram, Bratislava, Slovakia.

2. Scruton, R. (2009), Beauty. Oxford University Press, New York, NY.

3. Hegel, G. W.F., Aesthetics. Lectures on fine art, vol. I, Clarendon Press, Oxford, UK, 1975.

4. Sošková, J. (2007), "Otvorenost' klasických estetických kategórií pre súčasnú estetiku” [Openness of classical aesthetic categories for contemporary aesthetics], in Sošková, J. (ed.), Estetika - filozofia umenie III [Aesthetics - Philosophy - Art III], Filozofická fakulta Prešovskej univerzity v Prešove, Prešov, Slovakia, pp. 76-95.

5. Nancy, J. L. (1993), “The Sublime Offering”, in Courtine, J .F. and al. Of the Sublime: Presence in Questions: essays, State University of New York Press, New York, NY, pp. 25-53.

6. Danto, A. C. (1964), “Artworld", Journal of Philosophy, vol. 61, no. 19, pp. 571-584.

7. Hepburn, R. W. (1966), "Contemporary Aesthetics and the Neglect of Natural Beauty", in Williams, B. and Montefiori, A. (eds.), British Analytical Philosophy, Routledge and Kegan Paul, London, UK, pp. 285310 .

8. Dadějík, O. (2010), "Environmentální estetika" [Environmental aesthetics], in Zahrádka, P. (ed.), Estetika na prelomu milénia [Aesthetics at the turn of the millennium], Barrister \& Principal, Brno, Czech Republic, pp. 373-384.

9. Danto, A. (1998), "Konec uměni”" [End of Art], Estetika, vol. 35, pp. 1-18.

10. Shusterman, R. (1999), "Somaesthetics: A Disciplinary Proposal", Journal of Aesthetics and Art Criticism, vol. 57, p. 299-313.

11. Berleant, A. (1991), Art and Engagement, Temple University Press, Philadelphia, PA.

Received: January 2, 2018 Accepted: June 26, 2018

Author's information:

Adrián Kvokačka — PhD, Research assistant, adrian.kvokacka@ff.unipo.sk 


\section{Почему красота и почему сейчас? Исторические перспективы современного дискурса о красоте}

\section{Адриан Квокачка}

Прешовский университет, Словакия, 080 01, г. Прешов, ул. 17 ноября, стр. 15

Для цитирования: Kvokačka $A$. Why beauty and why now? Historical perspectives of the contemporary discourse on beauty // Вестник Санкт-Петербургского университета. Философия и конфликтология. 2018. Т. 34. Вып. 4. С. 515-522. https://doi.org/10.21638/spbu17.2018.405

Термин «красота» является ключевой категорией эстетики. Релевантность красоты искусства, которая была представлена в античной мысли трансцендентальной теорией красоты Платона или более фактуализированной, индуктивной теорией эмпирически ориентированного Аристотеля, а также многих других мыслителей, делала красоту одной из основных категорий, описывающих картину мира, в том числе и мира искусства. Современные подходы к исследованию красоты в основном восходят к идеалистической эстетике Канта и Гегеля, однако современное искусство и в целом эстетика XX столетия критически смотрят на красоту и даже сбрасывают ее с пьедестала. Имеет ли смысл сегодня заниматься теоретическим исследованием красоты в искусстве? Разве красота как атрибут искусства не закончила свой путь вместе с идеей конца искусства? Цель статьи - проследить коннотации утраты красотой места в современном искусстве в контексте «конца искусства» (Гегель и Данто) или конца его истории (Бельтинг). Современная новая тематизация красоты, в которой доминируют безобразное и возвышенное в искусстве (с точки зрения Канта и Лиотара), произвела существенные перемены, открыв красоту не только как обломок прошлого, но и как живой источник, который привлекает внимание ученых и благодаря современным междисциплинарным подходам открывает новые перспективы исследований.

Ключевые слова: эстетика, конец искусства, красота.

Контактная информация :

Адриан Квокачка - д-р филос., научный ассистент; adrian.kvokacka@ff.unipo.sk 